\title{
SARS-CoV-2 in wastewater from Mexico City used for irrigation in the Mezquital Valley: quantification and modeling of geographic dispersion
}

\author{
Yaxk'in Coronado $^{1} \cdot$ Roberto Navarro ${ }^{2} \cdot$ Carlos Mosqueda $^{2,3} \cdot$ Valeria Valenzuela $^{2,4} \cdot$ Juan Pablo Pérez $^{2}$. \\ Víctor González-Mendoza $^{1} \cdot$ Mayra de la Torre $^{2} \cdot$ Jorge Rocha $^{1}{ }^{1}$
}

Received: 7 June 2021 / Accepted: 28 July 2021 / Published online: 9 August 2021

(c) The Author(s), under exclusive licence to Springer Science+Business Media, LLC, part of Springer Nature 2021

\begin{abstract}
Quantification of SARS-CoV-2 in urban wastewaters has emerged as a cheap, efficient strategy to follow trends of active COVID-19 cases in populations. Moreover, mathematical models have been developed that allow the prediction of active cases following the temporal patterns of viral loads in wastewaters. In Mexico, no systematic efforts have been reported in the use of these strategies. In this work, we quantified SARS-CoV-2 in rivers and irrigation canals in the Mezquital Valley, Hidalgo, an agricultural region where wastewater from Mexico City is distributed and used for irrigation. Using quantitative RT-PCR, we detected the virus in six out of eight water samples from rivers and five out of eight water samples from irrigation canals. Notably, samples showed a general consistent trend of having the highest viral loads in the sites closer to Mexico City, indicating that this is the main source that contributes to detection. Using the data for SARS-CoV-2 concentration in the river samples, we generated a simplified transport model that describes the spatial patterns of dispersion of virus in the river. We suggest that this model can be extrapolated to other wastewater systems where knowledge of spatial patterns of viral dispersion, at a geographic scale, is required. Our work highlights the need for improved practices and policies related to the use of wastewater for irrigation in Mexico and other countries.
\end{abstract}

Keywords SARS-CoV-2 $\cdot$ Wastewater $\cdot$ Dispersion modeling $\cdot$ Irrigation Mezquital Valley

Supplementary information The online version contains supplementary material available at https://doi.org/10.1007/s00267021-01516-4.

Jorge Rocha

jorge.rocha@ciad.mx

1 Conacyt-Unidad Regional Hidalgo, Centro de Investigación en Alimentación y Desarrollo. Ciudad del Conocimiento y la Cultura de Hidalgo, Blvd. Santa Catarina S/N, San Agustín Tlaxiaca, Hidalgo, México42163

2 Unidad Regional Hidalgo. Centro de Investigación en Alimentación y Desarrollo, Ciudad del Conocimiento y la Cultura de Hidalgo, Blvd. Santa Catarina S/N, San Agustín Tlaxiaca, Hidalgo, México42163

3 Instituto Tecnológico de Celaya, Antonio García Cubas 600 , Fovissste, Celaya, Gto 38010, México

4 Universidad Tecnológica de Querétaro, Av. Pie de la Cuesta 2501, Nacional, Santiago de Querétaro, Qro. 76148, México

\section{Introduction}

The ongoing global pandemic of COVID-19 disease, caused by severe acute respiratory syndrome coronavirus 2 (SARS-CoV-2), is a public health emergency of international concern (Organization and Fund (UNICEF) 2020a, 2020b). SARS-CoV-2 ribonucleic acid (RNA) has been detected in feces from both symptomatic and asymptomatic patients (Chen et al. 2020; Holshue et al. 2020; Jiehao et al. 2020; Tang et al. 2020; W. Wang et al. 2020; Zhang et al. 2020) and in wastewater (Ahmed et al. 2020; Lodder and Husman 2020; Medema et al. 2020). For this reason, quantification of SARS-CoV-2 RNA in wastewater has emerged as a cheap, efficient method for monitoring active cases in large populations (Ahmed et al. 2020; S. Wang et al. 2020), small towns (Kitajima et al. 2020; Randazzo et al. 2020), or campuses (Harris-Lovett et al. 2021). Notably, since both symptomatic and asymptomatic individuals contribute to the viral load in wastewaters (Vallejo et al. 2020; Wu et al. 2020), this strategy allows for 
a)

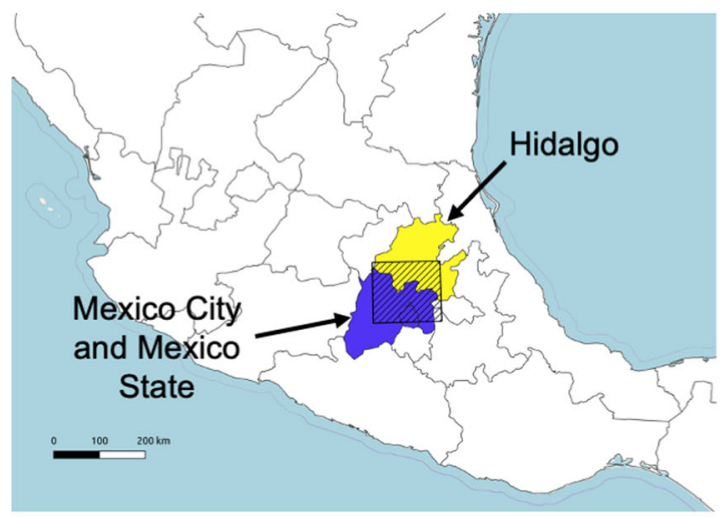

b)

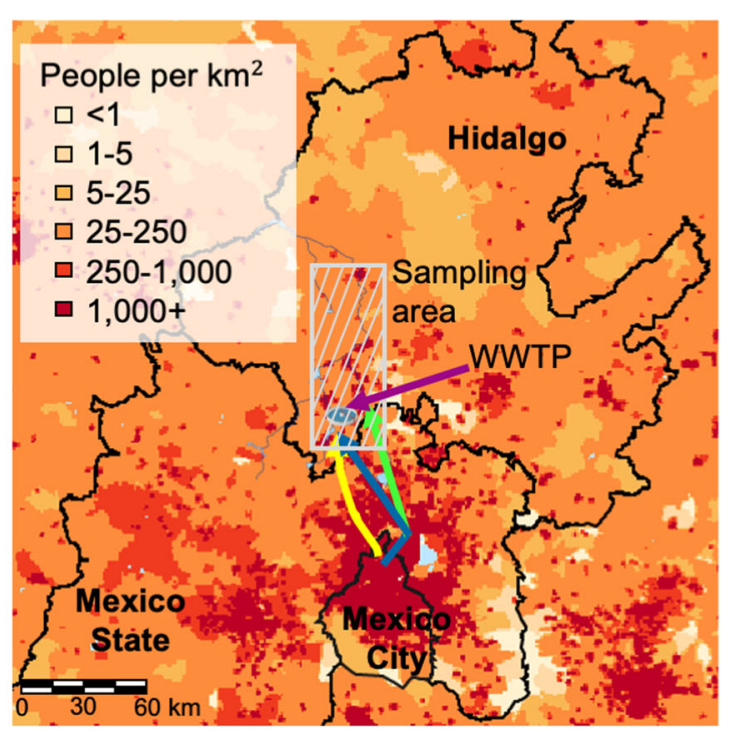

c)

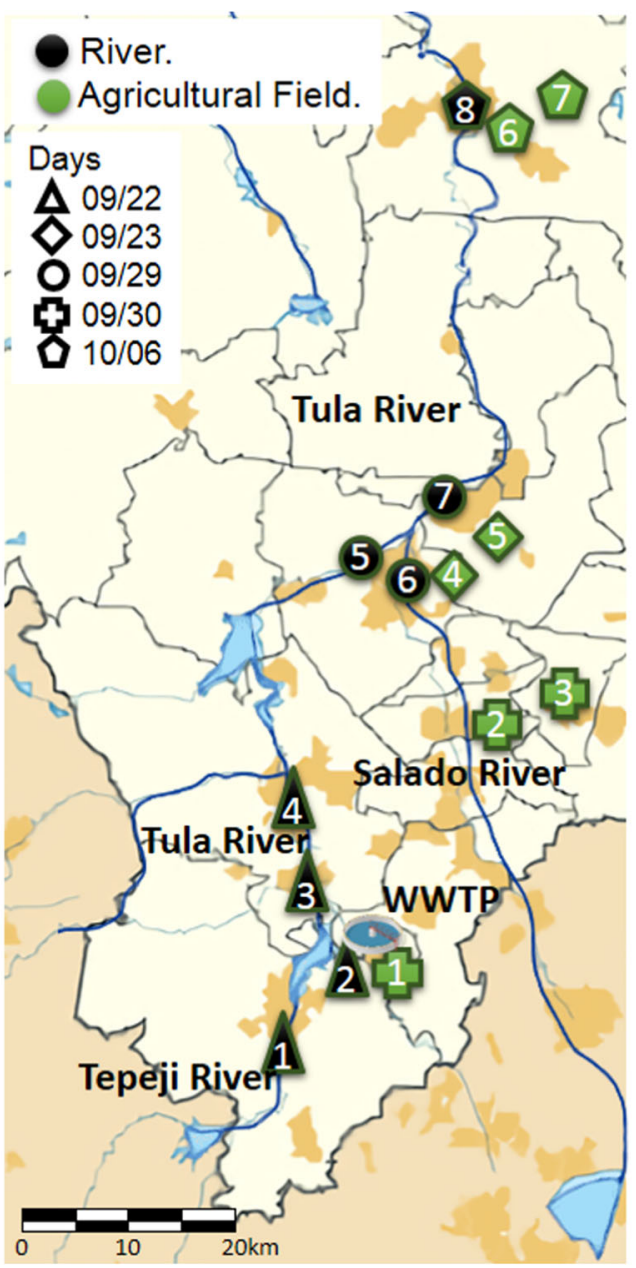

Fig. 1 Study area. a Location of the State of Hidalgo, in Mexico. Dashed area corresponds to Fig. 1b. b Mexico City is the main source of wastewater used for irrigation in the Mezquital Valley. HeatMap showing the population density in the study area. Arrows indicate the location and discharge of the main sewage systems: yellow, Central Interceptor Tunnel; blue, West Interceptor Tunnel; green, Grand

a one-week anticipation in the active cases, compared to health systems registries; i.e. an increase in recently infected individuals who remain asymptomatic may not be registered by health systems, but can be detected in wastewater viral loads (Lesimple et al. 2020; Medema et al. 2020; HarrisLovett et al. 2021).

Mexico City has more than 661,446 confirmed cases of COVID-19 (Mexico City Government 2021; consulted on June 1st, 2021); this is the city with the highest number of cases in the country. In Hidalgo, a state north of Mexican Valley Metropolitan Area (MVMA, Fig. 1a), more than 39,012 positive cases have accumulated (State of Hidalgo Government 2021), of which more than 11,000 cases (28\%) correspond to the Mezquital Valley, a highly productive agricultural region.

To date, no systematic efforts have been reported about detection of SARS-CoV-2 in wastewater in Mexico.
Drainage Canal. WWTP Wastewater treatment plant. Dashed area corresponds to Fig. 1c. c Sampling locations and dates for samples in the Mezquital Valley. For agricultural field locations, samples of both water (irrigation canal) and soil (adjacent agricultural field) were collected. Background map: orange areas indicate urbanized areas; blue areas indicate waterbodies

However, the Mezquital Valley has several characteristics that make the study of SARS-CoV-2 in wastewater relevant. This region is located $80 \mathrm{~km}$ north of Mexico City (Fig. 1). It is inhabited mainly by the indigenous Otomí group that speaks a native language called $h \tilde{n} \ddot{a} h \tilde{n} u$. The average annual precipitation is $409 \mathrm{~mm}$ (Moreno Alcántara et al. 2006) and the main economic activity is agriculture, but the arid climate contributes to the extreme poverty, historically associated to the region (SAGARPA 2003; Instituto Nacional de Lenguas Indígenas (Mexico) 2009; Rossette 2017). For this reason, wastewater is widely used for irrigation; it is received from Mexico City through the West Interceptor Tunnel, Central Interceptor Tunnel, and Grand Drainage Canal (Fig. 1b). Wastewater is partially processed in the wastewater treatment plant (WWTP) in Atotonilco de Tula, Hidalgo before feeding the Tula River and a complex system of irrigation canals (Fig. 1c) (Contreras et al. 2017). 
This represents a health and environmental risk (Lesser et al. 2018), as farmers, inhabitants and consumers in the Mezquital Valley are in contact with water, soil or agricultural products. However, the use of wastewater for irrigation is one of the main causes that allowed that this Valley is no longer in extreme poverty (García-Salazar and García-Salazar 2019).

Using data for SARS-CoV-2 concentration in wastewater, several models have been proposed for to find a correlation between the temporal patterns of viral concentration and the number of active COVID-19 cases (Hart and Halden 2020a). Likewise, a previous work presented the first model of spatial and temporal patterns of viral loads in seaway systems, showing the dispersion of the virus in an urban region (Hart and Halden 2020b). However, models for spatial patterns of viral dispersion are needed in open waterbodies that contain wastewater, in order to understand the virus transport and to identify the zones with higher risk of infection.

In this study we sampled water from the Tula River, Salado River and irrigation canals in the Mezquital Valley (Fig. 1), which receive wastewater from Mexico City, to assess the presence of SARS-CoV-2 and generate a mathematical model that describes its spatial dispersion. We propose that our results are highly relevant not only to follow the epidemic in Mexico City and municipalities in Hidalgo, but also to evaluate a possible risk of transmission through environmental matrices and measure the stability of SARS-CoV-2 with geographic resolution.

\section{Materials and methods}

\section{Sampling}

Between September 22nd and October 6th 2020, we collected water samples in eight locations of the Tula River, representing the main flow of wastewater from Mexico City in the Mezquital Valley, this also included two locations in the Salado River, which receives wastewater from the Grand Drainage Canal (sewage stream indicated with a yellow arrow in Fig. 1b), and Tepeji river, which contains wastewaters from local municipalities (Fig. 1c, Table 1). These samples were collected between the WWTP and Ixmiquilpan (Fig. 1). Water samples were also collected from irrigation canals adjacent to agricultural fields as well as soil samples from these agricultural fields (Fig. 1c, Table 1). Produce samples were also collected at three of the agricultural fields: a sample of coriander at site 3, and samples of lettuce at sites 6 and 7. In total, our sampling covered $\approx 80 \mathrm{~km}$ in the Mezquital Valley, and included the municipalities of Tepeji del Río, Atotonilco de Tula, Tula de Allende, Tezontepec de Aldama, Mixquiahuala de Juárez, Tlaxcoapan, Tetepango and Ixmiquilpan (Table 1).
Appropriate safety equipment was always used, consisting of a cotton lab coat, latex gloves, KN95 respiratormask, rubber boots, disposable cap, and safety glasses. A simple sampling technique was used (NOM, 1980; EPA, 2017), locating sites where the wastewater is well mixed near to the center of the flow channel, approximately between 40 and 60 percent of water depth, where turbulence is maximum, and there is minimum sedimentation of solids. For each location, three water samples were collected as follows: two samples of $400 \mathrm{ml}$ in glass bottles, for SARS-CoV-2 detection and for microbiological analyses; and one $4 \mathrm{~L}$ sample in a plastic bottle, for physicochemical analysis. In the case of samples for SARS-CoV-2 detection, a single sample was collected in each location of the Tula River, while duplicate samples were collected in each location for irrigation canals. For each water sample collected at an irrigation canal, we also sampled $500 \mathrm{~g}$ of soil from an adjacent agricultural field. All samples were immediately placed in ice until arrival at the laboratory. Water samples for SARS-CoV-2 detection were inactivated by incubation at $60^{\circ} \mathrm{C}$ for $1 \mathrm{~h}$ upon arrival at the laboratory.

\section{Physicochemical and microbiological analyses}

Samples for physicochemical and microbiological analyses were stored in ice from sampling until delivery to external laboratories where determinations were carried out. Due to the remoteness of sampling sites, analyses were performed between 18 to $40 \mathrm{~h}$ after sampling. Water samples were analyzed for physicochemical parameters at Laboratorio de Análisis Químicos Analíticos (LAQA), at Facultad de Química, Universidad Autónoma de Querétaro (Querétaro, México). Physicochemical parameters measured were: Biochemical oxygen demand (BOD), chemical oxygen demand (COD); $\mathrm{pH}$, total dissolved solids (TDS), suspended solids (SS), total suspended solids (TSS) and total solids (TS). Microbiological analysis of total coliforms (TC), fecal coliforms (FC), Escherichia coli and Salmonella (PCR detection) were analyzed (according to norm NOM-210-SSA-2014) at Laboratorio para la Evaluación y Control de Riesgos Microbianos en Alimentos (LECRIMA) at UAQ (Querétaro, México). The 'most probable number' method was used for quantification of TC, FC and E. coli.

\section{Viral RNA extraction}

Duplicate RNA extractions were performed for each sample collected for SARS-CoV-2 detection. For soil samples, viral particles were first eluted from $15 \mathrm{~g}$ of sample in $150 \mathrm{ml}$ of $10 \%$ beef extract buffer ( $\mathrm{pH} 7)$ by stirring for $30 \mathrm{~min}$ (Horm et al. 2012). Next, soil 


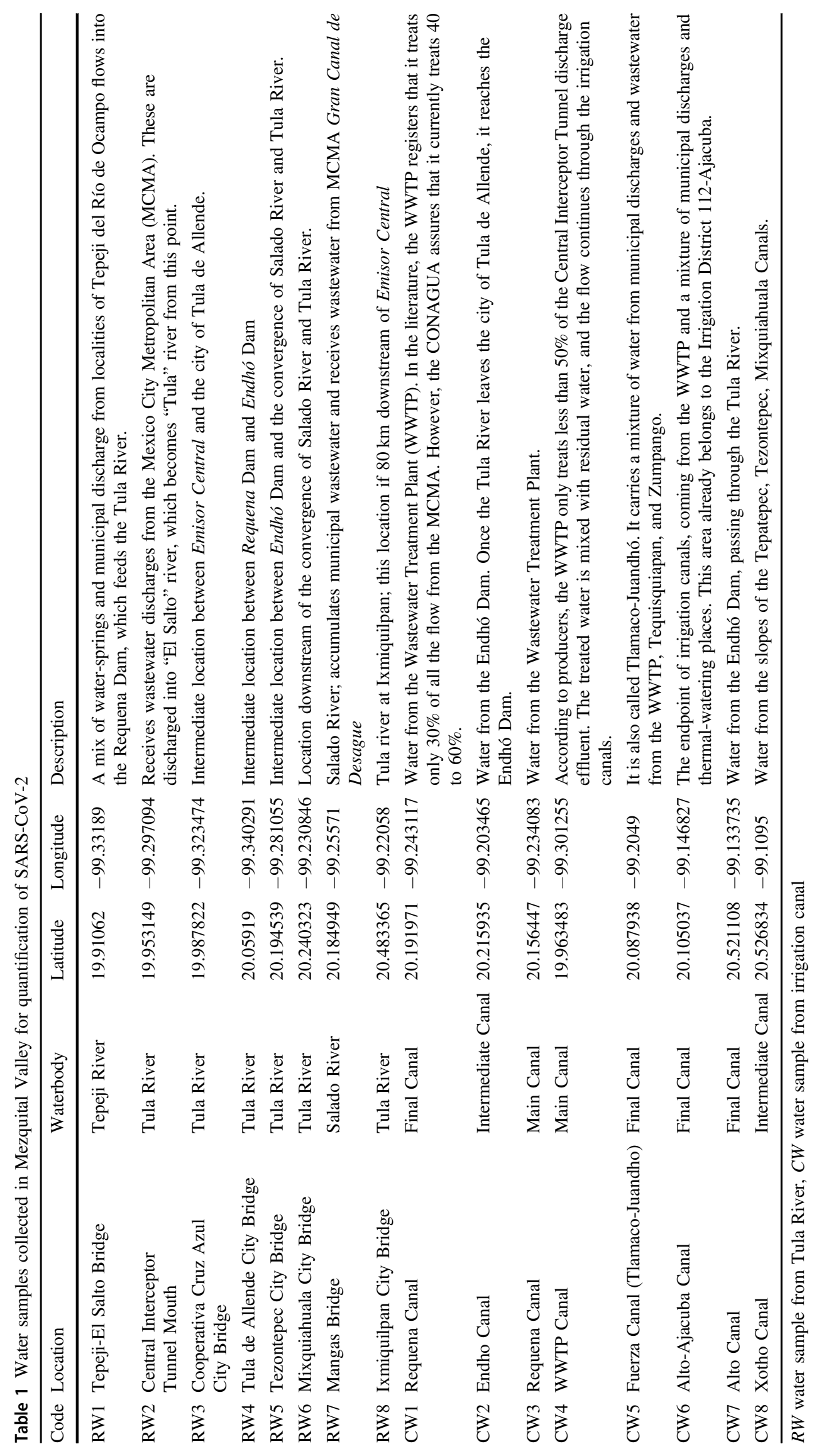


suspensions and inactivated wastewater samples $(150 \mathrm{ml})$ were processed following previously reported protocols (Kocamemi et al. 2020; Kumar et al. 2020; Wu et al. 2020) with slight adaptations. First, samples were filtered through a No. 5 Whatman filter (Millipore), and then through $0.22 \mu \mathrm{m}$ polyethersulfone membrane (Corning). Next, viral particles were precipitated by adding $\mathrm{NaCl}$ $(100 \mathrm{~g} / \mathrm{L})$ and Polyethilenglicol $6000(22 \mathrm{~g} / \mathrm{L})$ and stirring for $20 \mathrm{~min}$. Then, $105 \mathrm{ml}$ samples were centrifuged at $12,000 \times \mathrm{g}$ for $2 \mathrm{~h}$, and the resulting pellet was suspended in $400 \mu \mathrm{l}$ RNAse free water. Viral nucleic acids were extracted from these samples using the Purelink Viral DNA/RNA kit (Invitrogen), with an elution volume of $50 \mu$ l. Purified nucleic acid samples were quantified by spectrophotometry in a Nanodrop One (Thermo Scientific). RNAs from soil samples were further processed with the OneStep PCR Inhibitor Removal Kit (Zymo Research).

\section{Quantification of SARS-CoV-2 RNA}

For detection of SARS-CoV-2, the kit Decov2 Triplex (Genes2Life, Irapuato, Mexico) was used, which includes reverse transcription and PCR detection of three targets of $\mathrm{N}$ ORF (N1-FAM, N2-HEX and N3-TexasRed) in a single multiplex reaction. For each reaction, $5 \mu \mathrm{l}$ of viral RNA were added as template in a total volume of $25 \mu \mathrm{l}$. The RT-qPCR reaction was performed in a QuantStudio 5 (Thermo Scientific) instrument, and settings for passive reference was changed to 'none'. Duplicate SARS-CoV-2 detection reactions were performed for each RNA. For absolute quantification of SARSCoV-2 in environmental samples, a standard curve was obtained using synthetic RNA targets provided with the detection kit. For all RNA samples, we included an internal control reaction for the detection of Pepper Mild Mottle Virus (PMMV), using the primers Fwd 5'- GAG TGG TTT GAC CTT AAC GTT TGA-3', Rev 5'- TTG TCG GTT GCA ATG CAA GT-3' and probe 5'-FAM- CCT ACC GAA GCA AAT G-BHQ1-3 (Zhang et al. 2005; Haramoto et al. 2020).

\section{Modeling of water dispersion of SARS-CoV-2 in the Tula River}

The transport model for dispersion of virus in unsaturated media (Torkzaban et al. 2006) was adapted. The original model describes the viral concentration with respect to the distance from the virus input site and the decrease over time, and considers terms of adsorption and detachment of virus with respect to the soil-water interface and air-water interface. We considered only dispersion in the water bulk; we also considered that dispersion of virus is independent on time, and it depends on the distance. Hence, the attachment and detachment rate coefficients and the inactivation rate coefficient in soil and air media were equal to zero $\left(\kappa_{\text {att }}^{\mathrm{a}}=0, \kappa_{\text {det }}^{\mathrm{a}}=0, \kappa_{\text {att }}^{\mathrm{s}}\right.$ $=0, \kappa_{\text {det }}^{\mathrm{s}}=0, \mu_{\mathrm{s}}=0$ and $\left.\mu_{\mathrm{a}}=0\right)$. We also assume that Darcy flux $(\mathrm{q})$ and inactivation rate coefficient $\left(\mu_{\mathrm{w}}\right)$ are constant along the river. The variables amount of water $(\theta)$ and coefficient of dispersion (D) were fitted to the experimental data. Finally, we excluded the contributions of the adsorption from the general model and considered two entrances corresponding to the Tepeji River at $5.88 \mathrm{~km}$ and the Salado River at $57.88 \mathrm{~km}$ (with respect to RW2; Figs. 1c and 2a), both of which affect the viral concentration (Supplementary File 1). Detailed derivation of the equations is shown in Supplementary File 1. The resulting Eq. (1) is shown below:

$\frac{\partial \theta C_{W}}{\partial t}=\frac{\partial}{\partial X}\left(\theta D \frac{\partial C_{W}}{\partial X}\right)-\frac{\partial q C_{W}}{\partial X}-\mu_{w} \theta C_{w}$

where $\mathrm{Cw}$, is the viral concentration and the other variables are previously decribed.

The equation was solved numerically with initial and boundary conditions of initial distance of zero at the point RW2 corresponding to the Tepeji River (as this is the initial entrance of water to the Tula River) and an initial normalized viral concentration at the point RW2, according to the maximum value obtained by the experimental measurements. We used the software package Scipy Odeint in Python. The concentration values for the virus in the Tula River were obtained experimentally as described above.

a)

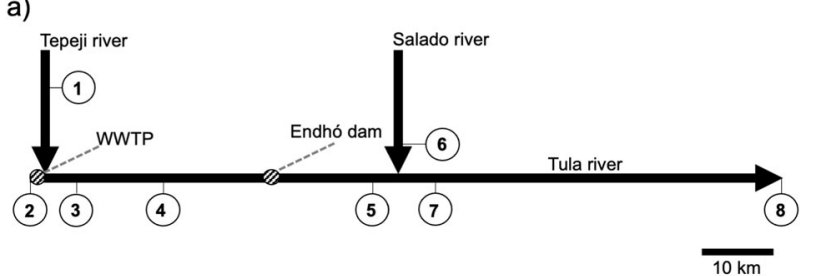

b)

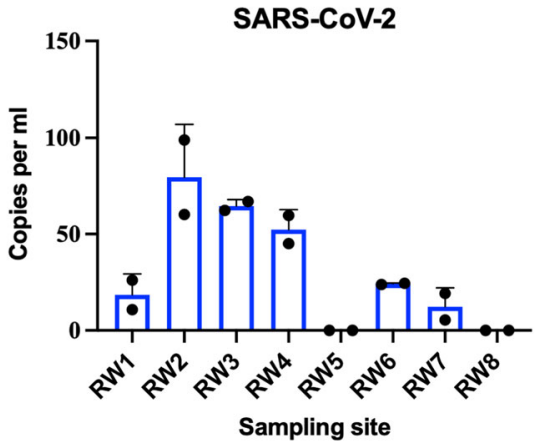

Fig. 2 Quantification of SARS-CoV-2 ARN in water samples from the Tula River. a Schematic representation of distances and fluxes present between the sampling locations at the Tula, Tepeji, and Salado River. WWTP Wastewater treatment plant. b RT-qPCR results of SARS$\mathrm{CoV}-2$ quantification in the Tula River 


\section{Results}

\section{SARS-CoV-2 quantification in water samples from Tula River}

We detected RNA from SARS-CoV-2 in water samples collected in the Tula River, Tepeji River and Salado River (Fig. 2). Detection was achieved from the three targets included in the kit (N1-FAM, N2-HEX and N3-TexasRed) in most cases; however, quantification using N2-HEX Ct values and its corresponding standard curve yielded more consistent results, and absolute values were always intermediate to those obtained with N1-FAM and N3-TexasRed (not shown). From these criteria, in this study we used N2HEX data; for this probe and following the protocols detailed in methods, we calculated a limit of detection of $<1$ copy per ml of water sample. SARS-CoV-2 RNA was detected in six out of eight water samples from river (Fig. 2). As expected, the highest concentration was found in sample RW2, at the entrance flow of the wastewater treatment plant (WWTP, Figs. 1c and 2), with a concentration of 79 RNA copies per $\mathrm{ml}$; from the sampled locations in the Tula River, this is the closest to the Mexican Valley Metropolitan Area (MVMA; Figs. 1 and 2). This value decreased through the flow of the river (which consists mostly of untreated wastewater) in samples RW3 and RW4, and was undetectable in RW5, downstream of the Endhó Dam. SARS-CoV-2 was also detected at the entrance fluxes of Tepeji River (RW1, 18 copies per ml) and Salado River (RW6, 24 copies per ml), both of which contribute to viral load in the Tula River. Finally, SARS-CoV-2 was not detected in sample RW8, which was collected at Ixmiquilpan, $\approx 40 \mathrm{~km}$ downstream of sample RW7 (Fig. 2).

\section{SARS CoV-2 RNA in irrigation canals}

RNA from SARS-CoV-2 was also detected in water samples collected in irrigation canals throughout the Mezquital Valley. Irrigation canals are mostly fed from treated water, however, untreated wastewaters from municipalities in Hidalgo are also connected to these canals. Since the irrigation canal network in the Mezquital Valley is highly complex and a detailed map is unavailable, we only show the general known source of water in each location (Fig. 3a). RNA From SARS-CoV-2 was detected in 5 out of 8 water samples collected from irrigation canals (Fig. 3b). The highest concentration of 112 copies per $\mathrm{ml}$ was found in sample CW1 (Fig. 3b). This location is the closest from MVMA, however, it is reportedly fed solely from wastewater treated in the WWTP (Fig. 3a, Table 1). SARS-CoV2 RNA was also detected in samples CW2, CW4, CW4-II and CW5, all of which are fed from the WWTP, but also from wastewater from municipalities in Hidalgo, and from a)

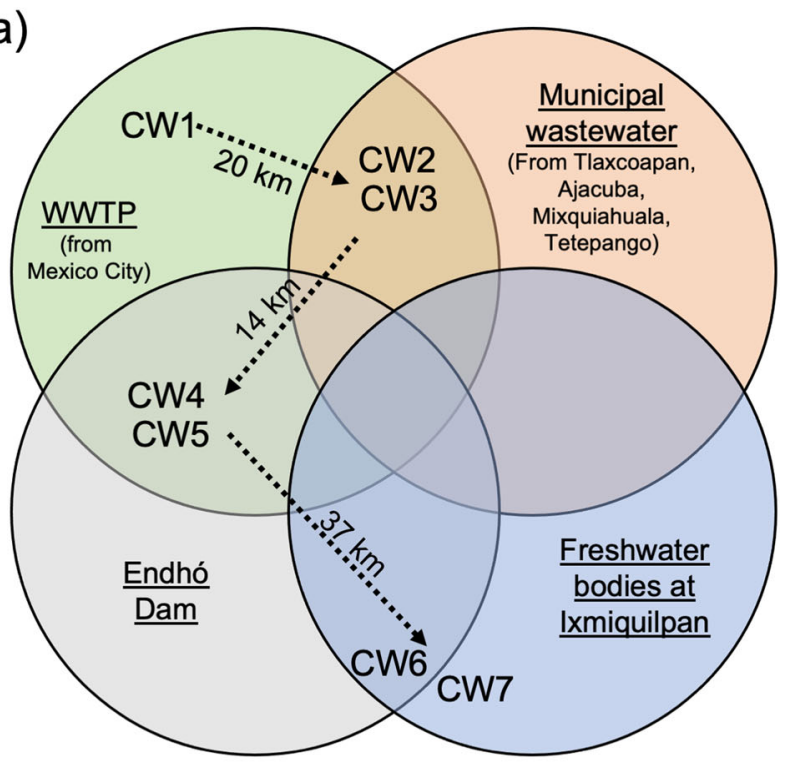

b) SARS-CoV-2

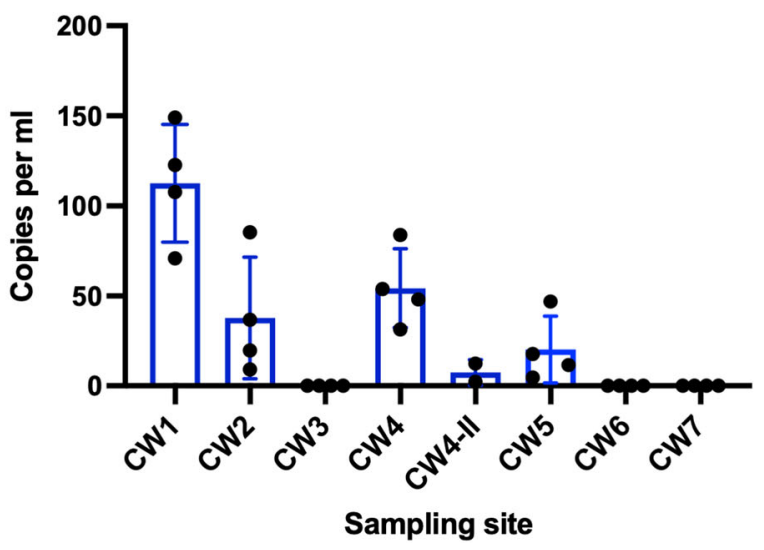

Fig. 3 Quantification of SARS-CoV-2 ARN in water from irrigation canals in the Mezquital Valley. a Schematic representation showing the reported source of water in irrigation canals sampled. b RT-qPCR results of SARS-CoV-2 quantification in water samples from irrigation canals

the Endhó Dam (Fig. 3). SARS-CoV-2 was not detected in samples CW3, CW6 and CW7; notably, irrigation canals at Ixmiquilpan (CW6 and CW7) are fed from freshwater bodies (not wastewater) such as groundwater wells or local spas. In contrast, CW3 is reportedly fed from the WWTP and local municipalities (Fig. 3) and lack of detection in this specific location may be related to degradation or dilution along the flow through the complex canal system, where distance from urban sources is mostly unknown.

Since SARS-CoV-2 RNA was detected in water samples from irrigation canals, we hypothesized that it may be detectable in agricultural soil from adjacent fields (Fig. 1c, Table 1). However, SARS-CoV-2 was not detected in these samples (Supplementary Table S1 and S2). Similarly, 
Table 2 Correlation of SARSCoV-2 quantification versus physicochemical and microbiological parameters in water samples

\begin{tabular}{|c|c|c|c|c|c|c|}
\hline \multirow[t]{2}{*}{ Parameter } & \multicolumn{3}{|c|}{ River water samples } & \multicolumn{3}{|c|}{ Irrigation canal samples } \\
\hline & $r^{2}$ & $p$ value & Significance & $r^{2}$ & $p$ value & Significance \\
\hline \multicolumn{7}{|c|}{ Physicochemical parameters } \\
\hline BOD & 0.66451416 & 0.00872825 & $* *$ & 0.11417103 & 0.40483251 & - \\
\hline COD & 0.94529181 & $7.42 \mathrm{E}-06$ & $* * *$ & 0.0181819 & 0.74745041 & - \\
\hline $\mathrm{pH}$ & 0.68970848 & 0.0064762 & $* *$ & 0.42338299 & 0.06905202 & - \\
\hline TDS & 0.24418989 & 0.20131137 & - & 0.3650173 & 0.10036602 & - \\
\hline SS & 0.86636172 & 0.00024926 & $* * *$ & 0.00302837 & 0.89594555 & - \\
\hline TSS & 0.26441269 & 0.18013422 & - & 0.01181227 & 0.79562296 & - \\
\hline TS & 0.17469837 & 0.29241941 & - & 0.35416452 & 0.10724613 & - \\
\hline \multicolumn{7}{|c|}{ Microbiological parameters } \\
\hline $\mathrm{TC}$ & 0.82551851 & 0.00070422 & $* * *$ & 0.21502632 & 0.23573855 & - \\
\hline FC & 0.80436747 & 0.00109741 & $* * *$ & 0.35713184 & 0.10532899 & - \\
\hline E. coli & 0.80436747 & 0.00109741 & $* * *$ & 0.40315677 & 0.07888845 & - \\
\hline
\end{tabular}

$B O D$ Biochemical oxygen demand, $C O D$ chemical oxygen demand, $p H$ Hydrogen potential, $T D S$ total dissolved solids, SS suspended solids, TSS total suspended solids, TS total solids, TC total coliforms, FC fecal coliforms

$* * p<0.01, * * * p<0.005$
SARS-CoV-2 RNA was not detected in any of the produce samples, which were collected in the field or at the Ixmiquilpan Market (Table 1, Supplementary Table S2). Since the internal control PMMV was detected in all of these samples (Supplementary Table S2), we discard the presence of PCR inhibitors as the reason for lack of detection, but further studies are needed to confirm the absence of SARSCoV-2 since viral particles can adsorb to soil particles and other solids.

\section{Physicochemical and microbiological analyses of water samples}

Results on physicochemical analyses are shown in Supplementary Table S3 and results on microbiological analyses are shown on Supplementary Table S4. Based on standards established by Mexican laws, all water samples had values of BOD, TSS and SS below the permitted limits for water used for irrigation (NOM-001-SEMARNAT1996). Regarding limits for microbiological parameters (NOM-001-ECOL-1996), five out of eight water samples from the Tula River, and 5 out of 8 water samples from irrigation canals, presented total coliform values above the allowed limits for wastewater used for irrigation (Supplementary Table S4).

We assessed if the physicochemical characteristics of wastewater, organic matter and microbial concentration correlated with the concentration of the virus. In samples from the river water, correlation analyses showed that several variables were associated with SARS-CoV-2 RNA concentration (Table 2, left). In contrast, analyses using parameters obtained from irrigation canals, showed no significant correlations between SARS-CoV-2 RNA concentration and physicochemical or microbiological variables (Table 2, right). Significant $p$ values were obtained for correlation analyses with physicochemical parameters BOD, COD, pH, and SS (Table 2, left), and also for all three microbiological parameters in river samples (Table 2, Supplementary Fig. S1). Further inspection of correlation trends revealed correlations with $\mathrm{pH}$ and SS could be spurious, since they were highly grouped in discrete values (Supplementary Fig. S1), and a higher number of samples should be analyzed to confirm these observations (Table 1, Suplementary Fig. S1).

COD and BOD are measurements of oxygen required for chemical oxidation of organic material in water. From these values, the Biodegradability index can be calculated (COD/ BOD ratio) as an indicator of the non-biodegradable organic-chemicals. We assessed if the Biodegradability index correlated with the virus concentration of the water system (Abdalla and Hammam 2014); interestingly, we found a clear correlation between Biodegradability index and SARS-CoV-2 concentration in samples from the Tula River (Supplementary Fig. S2).

\section{Modeling the geographic dispersion of SARS-CoV-2 in the Mezquital Valley}

Using data for SARS-CoV-2 concentration in the Tula River, we sought to adapt a model that describes viral dispersion in the wastewater bulk. Our model only considers the dispersion of the virus in water and the modification of the flux in the mainstream. The dispersion coefficient was calculated through least square optimization 
a) Viral ARN in the Tula river

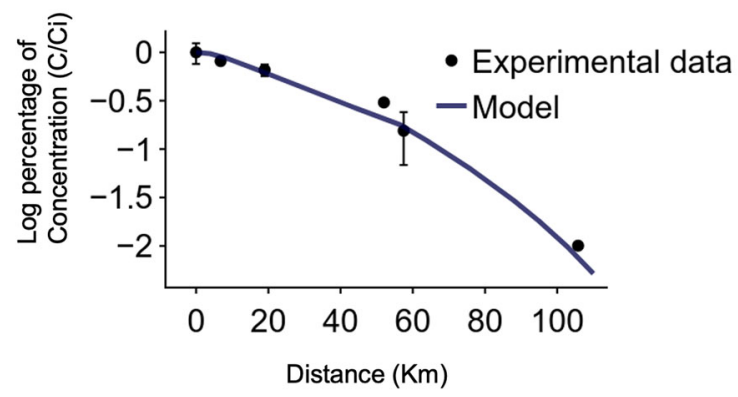

b) Geographic distribution
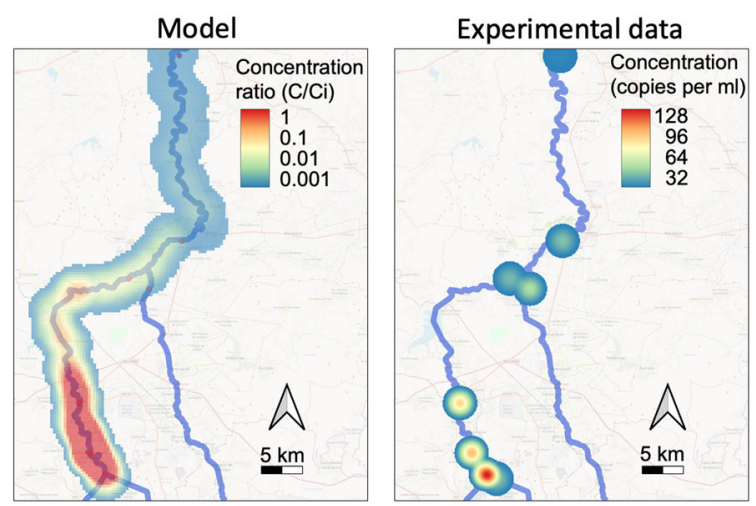

Fig. 4 The transport model generated for SARS-CoV-2 dispersion in the Tula River, fits the data obtained experimentally. a Graphic representation of viral concentration in the Tula River, comparing the experimental data and the transport model obtained in this study. b Map representation of the geographic dispersion of SARS-COV-2 presence in the Tula River, comparing the transport model (left) and the experimental data (right)

to the experimental data (Suplementary File 1) (Molugaram et al. 2017). The concentration in the initial sampling site RW2 (Fig. 1c) was normalized to one (Ratio of Concentration C/initial Concentration $\mathrm{Ci}$ ); since it was the maximum value, the experimental data were normalized to this value. Additionally, we modeled two entrances at the points RW2 and RW6, as a result the dispersion coefficient increases at these points. The model fitted to the experimental data along the Tula River (Fig. 4a). Therefore, with only three variables, dispersion coefficient $(D)$, amount of water $(\Theta)$ and a distance function of $D[D(\mathrm{x})]$, we could define the dispersion of the virus in the Tula River. Finally, we used QGIS3 to obtain a geographic representation of our model and the experimental data (Fig. 4b), which show the general trends of SARS-CoV-2 dispersion in the Tula River.

\section{Discussion}

In this work, we quantified SARS-CoV-2 RNA in wastewaters from Mexico City, which are distributed throughout the Tula River, Salado River and irrigation canals and are used for irrigation of crops in the Mezquital Valley. Notably, we detected the virus in geographically representative water samples from both rivers and the irrigation canals. With our data, we generated a viral dispersion model which can be used to assess concentration of SARS-CoV-2 to other river systems if the dispersion coefficient $(D)$, amount of water $(\Theta)$ and a distance function of $D[D(\mathrm{x})]$ of the river are fitted.

Samples from both the Tula River and irrigation canals followed the same general trend of presenting the highest concentration in the sites located near the WWTP. Viral concentration decreased in the remaining sites and was undetectable in the northernmost sites, located near the town of Ixmiquilpan. This result indicates that the most important source of SARS-CoV-2 RNA in these water systems is the wastewater from Mexican City Valley, and that the viral particles tend to degrade or dilute along the flow of water through the Mezquital Valley. However, we do not discard that municipalities in the Mezquital Valley contribute to viral load and fecal contamination of Tula River, Salado River and the irrigation canals.

Our results showed that the SARS-CoV-2 virus was not detected on soil samples. While this could be related to PCR inhibitors in the samples, we found that the PMMV virus was detected and hence this hypothesis was discarded. Virus associate with soil and other particulate matter and both adsorption and detachment of virus depends on temperature, moisture, $\mathrm{pH}$, and the physicochemical characteristics of the virus capsid surface and the particles. Similarly, the microbes and organic matter may have a protective effect on virus (AzadpourKeeley et al. 2003). Further studies are needed to asses if lack of detection of SARS-CoV-2 is related to degradation or dispersion of the virus, or alternatively, if viral particles adsorb in the soil matrix, which would make our RNA extraction method not appropriate.

We found that physicochemical variables COD and BOD and microbiological variables showed significant correlations with SARS-CoV-2 quantification, but only in samples from the Tula River. However, these observations should be confirmed with measurements in a higher number of samples. This result suggests that in the river, anthropological sources from a single source of contamination predominate, i.e. the MVMA. However, irrigation canals - where no correlations were found - may receive other sources of contamination (from agriculture, livestock, or industry) (Guédron et al. 2014; Lesser et al. 2018). Furthermore, our correlation analyses suggest that $\mathrm{BOD}, \mathrm{COD}$, and the Biodegradability Index (BOD/COD), as well as fecal coliforms may be good indicators of SARS-CoV-2 RNA concentration in municipal wastewaters. 
The model proposed to explain the dispersion of SARSCoV-2 virus along the Tula River, as well as the experimental data, indicate that the viral concentration decreases from south to north, with an initial dispersion point at the entrance of the Tula River at the WWTP and a minimal contribution from the communities along the Mezquital Valley (Fig. 4a, b). Our model predicts viral dispersion in the Mezquital Valley, and may be useful for the selection of sampling locations prior to temporal monitoring to quantify the evolution of SARS-CoV-2 (or other virus) epidemics in populations. Previously available models for viral dispersion in environmental matrices (Bivins et al. 2020; Farkas et al. 2020; Kitajima et al. 2020) are useful for detailed dissection of variables governing dispersion patterns of viral particles in at a smaller scale in controlled environments. Our model is, to our knowledge, the first to allow prediction of viral dispersion in linear water bodies at a geographic scale. This model could be extrapolated to other wastewater streams, rivers, canals, etc.

One important purpose of this work was to assess the possible risk of environmental transmission of SARS-CoV2 through environmental matrices. Indeed, some recent reports suggest that the virus may be infective (Kitajima et al. 2020), and hence, direct contact with water bodies in the Mezquital Valley may represent a risk of transmission, especially for farmers during flooding irrigation (Lüneberg et al. 2018). While our results suggest that improved wastewater treatment processes are needed as the WWTP normally works at $30 \%$ of its capacity (Chamizo-Checa et al. 2020), it is important to note that the producers refuse to use the treated water in their irrigation systems. Indeed, wastewaters contribute with large amounts of organic matter decreasing the costs of fertilization. In turn, increased wastewater treatment could directly elevate production costs, price of water, and needs for fertilizers, which could negatively impact land rentability (Pérez Camarillo 2002; Pérez et al. 2006; SIAP 2018).

This work does not seek to eliminate wastewater usage in the Mezquital Valley, as this practice is one of the key factors that allowed the economic development of the region. In fact, the Mezquital Valley is considered a study model for the agricultural development of arid and semiarid rural regions (Anderson 2020; Bonvehi Rosich and Seth Denizen 2021; Seth Denizen 2021). We suggest that our work should be considered - along with social, economic and agronomic factors--for the creation and modification of practices and policies related to water treatment (Belhadi et al. 2020), pathogen monitoring, agricultural practices, and safety measures for farmers in the Mezquital Valley. Finally, our results support the widespread notion that wastewater surveillance is an efficient method to follow transmission of SARS-CoV-2 in populations, especially in low-income regions where massive testing is not economically viable. Furthermore, the information generated through these strategies could also feed the decision-making processes during vaccination programs, by focusing efforts in populations with high-incidence.

Acknowledgements This work was supported by CONACyT, Mexico, grant 312014 for JR. This work was possible thanks to the collaboration of local farmers in the state of Hidalgo, who allowed us to collect samples in their fields. The authors thank Gabriela Rivas (UPFIM), Ana Alcalá (IBT UNAM), Laura Palomares (IBT), Oscar Monroy (UAMI) and Jesús Hernández (CIAD Hermosillo) for advice and technical assistance. Eneas Aguirre guided the sample collections at milpas from San Agustin Tlaxiaca. We thank personnel from governmental institutions in the state of Hidalgo: Jaime Ortega (SEDAGROH), Sergio Guzman (CONAGUA) and José Alonso Huerta (CITNOVA), for their valuable contribution in the stages of planning, sampling, and discussion of results.

\section{Compliance with ethical standards}

Conflict of Interest The authors declare no competing interests.

Publisher's note Springer Nature remains neutral with regard to jurisdictional claims in published maps and institutional affiliations.

\section{References}

Abdalla KZ, Hammam G (2014) Correlation between biochemical oxygen demand and chemical oxygen demand for various wastewater treatment plants in Egypt to obtain the biodegradability indices. Int J Sci 13(1):7

Ahmed W et al. (2020) First confirmed detection of SARS-CoV-2 in untreated wastewater in Australia: a proof of concept for the wastewater surveillance of COVID-19 in the community. Sci Total Environ 728:138764. https://doi.org/10.1016/j.scitotenv. 2020.138764

Anderson, A. (2020) The Right to Sewage: Agriculture, climate change, and the growing need for cities to embrace wastewater reuse, Harvard Graduate School of Design. Available at: https://www.gsd.harvard.edu/2020/09/the-right-to-sewage-a griculture-climate-change-and-the-growing-need-for-cities-toembrace-wastewater-reuse/ (Accessed 28 May 2021)

Belhadi A et al. (2020) Infectious waste management strategy during COVID-19 Pandemic in Africa: an integrated decision-making framework for selecting sustainable technologie. Environ Manag 66(6):1085-1104. https://doi.org/10.1007/s00267-020-01375-5

AzadpourKeeley A, Faulkner P, Chen J (2003) Movement and Longevity of Viruses in the Subsurface. Environmental Protection Agency, EPA, EPA/540/S-03/500, Washington, DC, p 25

Bivins A et al. (2020) 'Wastewater-based epidemiology: global collaborative to maximize contributions in the fight against COVID19'. Environ Sci Technol 54(13):7754-7757. https://doi.org/10. 1021/acs.est.0c02388

Bonvehi Rosich, M. and Seth Denizen, K. (2021) New Visions for Wastewater Equity in The Mezquital Valley, MCI. Available at: https://research.gsd.harvard.edu/mci/gsd-professors-and-studentspropose-new-visions-for-wastewater-equity-in-the-mezquital-va 1ley/ (Accessed 28 May 2021)

Chamizo-Checa S et al. (2020) Megacity wastewater poured into a nearby basin: looking for sustainable scenarios in a case study. Water 12(3):824. https://doi.org/10.3390/w12030824 
Chen Y et al. (2020) The presence of SARS-CoV-2 RNA in the feces of COVID-19 patients. J Med Virol 92(7):833-840. https://doi. org/10.1002/jmv. 25825

Contreras JD et al. (2017) Health risks from exposure to untreated wastewater used for irrigation in the Mezquital Valley, Mexico: A 25-year update. Water Res 123:834-850. https://doi.org/10.1016/ j.watres.2017.06.058

Farkas K et al. (2020) Wastewater and public health: the potential of wastewater surveillance for monitoring COVID-19. Curr Opin Environ Sci Health 17:14-20. https://doi.org/10.1016/j.coesh. 2020.06.001

García-Salazar, E. M. and García-Salazar, E. M. (2019) El agua residual como generadora del espacio de la actividad agrícola en el Valle del Mezquital, Hidalgo, México, Estudios sociales. Revista de alimentación contemporánea y desarrollo regional, 29(54). https://doi.org/10.24836/es.v29i54.741

Guédron S et al. (2014) (Methyl)mercury, arsenic, and lead contamination of the world's largest wastewater irrigation system: the Mezquital Valley (Hidalgo State-Mexico). Water, Air, Soil Pollut 225(8):2045. https://doi.org/10.1007/s11270-014-2045-3

Haramoto E et al. (2020) First environmental surveillance for the presence of SARS-CoV-2 RNA in wastewater and river water in Japan. Sci Total Environ 737:140405. https://doi.org/10.1016/j. scitotenv.2020.140405

Harris-Lovett $\mathrm{S}$ et al. (2021) Wastewater surveillance for SARS-CoV2 on college campuses: initial efforts, lessons learned, and research needs. Int J Environ Res Public Health 18(9):4455. https://doi.org/10.3390/ijerph18094455

Hart OE, Halden RU (2020a) Simulated 2017 nationwide sampling at 13,940 major U.S. sewage treatment plants to assess seasonal population bias in wastewater-based epidemiology. Sci Total Environ 727:138406. https://doi.org/10.1016/j.scitotenv.2020. 138406

Hart OE, Halden RU (2020b) Modeling wastewater temperature and attenuation of sewage-borne biomarkers globally. Water Res 172:115473. https://doi.org/10.1016/j.watres.2020.115473

Holshue ML et al. (2020) First case of 2019 novel coronavirus in the United States'. N Engl J Med 382(10):929-936. https://doi.org/ 10.1056/NEJMoa2001191

Horm VS et al. (2012) Highly pathogenic influenza A(H5N1) virus survival in complex artificial aquatic biotopes. PLOS ONE 7(4): e34160. https://doi.org/10.1371/journal.pone.0034160

Instituto Nacional de Lenguas Indígenas (Mexico) (ed.) (2009) Catálogo de las lenguas indígenas nacionales: variantes lingüísticas de México con sus autodenominaciones y referencias geoestadísticas. 1. ed. México, D.F: Instituto Nacional de Lenguas Indígenas

Jiehao C et al. (2020) A case series of children with 2019 novel coronavirus infection: clinical and epidemiological features. Clin Infect Dis 71(6):1547-1551. https://doi.org/10.1093/cid/ciaa198

Kitajima M et al. (2020) SARS-CoV-2 in wastewater: State of the knowledge and research needs. Sci Total Environ 739:139076. https://doi.org/10.1016/j.scitotenv.2020.139076

Kocamemi, B. A. et al. (2020) SARS-CoV-2 Detection in Istanbul Wastewater Treatment Plant Sludges, medRxiv, 2020.05.12.20099358. https://doi.org/10.1101/2020.05.12.20099358

Kumar M et al. (2020) First proof of the capability of wastewater surveillance for COVID-19 in India through detection of genetic material of SARS-CoV-2. Sci Total Environ 746:141326. https:// doi.org/10.1016/j.scitotenv.2020.141326

Lesimple A et al. (2020) The role of wastewater treatment plants as tools for SARS-CoV-2 early detection and removal. J Water Process Eng 38:101544. https://doi.org/10.1016/j.jwpe.2020. 101544

Lesser LE et al. (2018) Survey of 218 organic contaminants in groundwater derived from the world's largest untreated wastewater irrigation system: Mezquital Valley, Mexico. Chemosphere 198:510-521. https://doi.org/10.1016/j.chemosphere. 2018.01.154

Lodder W, de R.Husman AM (2020) SARS-CoV-2 in wastewater: potential health risk, but also data source. Lancet Gastroenterol Hepatol 5(6):533-534. https://doi.org/10.1016/S2468-1253(20) 30087-X

Lüneberg K et al. (2018) Drylands soil bacterial community is affected by land use change and different irrigation practices in the Mezquital Valley, Mexico. Sci Rep. 8(1):1413. https://doi.org/10. 1038/s41598-018-19743-x

Medema G et al. (2020) Presence of SARS-Coronavirus-2 RNA in sewage and correlation with reported COVID-19 prevalence in the early stage of the epidemic in the Netherlands. Environ Sci Technol Lett 7(7):511-516. https://doi.org/10.1021/acs.estlett.0c00357

Mexico City Government (2021) Available at: https://datamexico.org/ es/coronavirus

Molugaram K et al. (2017) Statistical Techniques for Transportation Engineering. Butterworth-Heinemann

Moreno Alcántara B, Garret Ríos MG, Fierro Alonso U (2006) Otomoíes del Valle del Mezquital. 1. ed. CDI, Comisión Nacional para el Desarrollo de los Pueblos Indígenas (Pueblos indígenas del México contemporáneo), México, D.F

Organization, W. H. and Fund (UNICEF), U. N. C. (2020a) Statement on the second meeting of the International Health Regulations (2005) Emergency Committee regarding the outbreak of novel coronavirus (2019-nCoV). Available at: https://www.who.int/ news/item/30-01-2020-statement-on-the-second-meeting-of-theinternational-health-regulations-(2005)-emergency-committeeregarding-the-outbreak-of-novel-coronavirus-(2019-ncov) (Accessed 27 May 2021)

Organization, W. H. and Fund (UNICEF), U. N. C. (2020b) Water, sanitation, hygiene, and waste management for the COVID-19 virus: interim guidance, 19 March 2020. Available at: https://a pps.who.int/iris/handle/10665/331499 (Accessed 27 May 2021)

Pérez, C. J. P., Zacatenco, G. M. G. and Martínez, M. M. (2006) Evolución del rendimiento y de la producción de maíz de riego en el Valle del Mezquital, INIFAPSAGARPA. Pachuca, Hidalgo. Publicación especial, (14)

Pérez Camarillo, J. P. (2002) Carbón de la Espiga de Maíz. Descripción, síntomas y prevención. INIFAP-CIRCE-C.E. Pachuca. FHP. Available at: https://www.google.com/url?sa $=\mathrm{t} \& \mathrm{rct}=\mathrm{j} \& \mathrm{q}=$ $\&$ esrc $=$ s\&source $=$ web\& $\mathrm{cd}=\&$ ved $=2$ ahUKEwji8fW-nPXw AhUHXK0KHdS-AX8QFjAAegQIAxAD\&url $=\mathrm{http} \% 3 \mathrm{~A} \% 2 \mathrm{~F} \%$ 2Fpublico.senasica.gob.mx\%2Fincludes\%2Fasp $\% 2$ Fdownload. asp\%3FIdDocumento\%3D26871\%26IdUrl\%3D67966\%26objeto \%3DP\%25E1gina\%26IdObjetoBase\%3D6073\%26down\% 3Dtrue\&usg=AOvVaw3KIZVvMjGFYFnRD0uzPzRG

Randazzo W et al. (2020) SARS-CoV-2 RNA in wastewater anticipated COVID-19 occurrence in a low prevalence area. Water Res 181:115942. https://doi.org/10.1016/j.watres.2020.115942

Rossette, A. (2017) En este pueblo mexicano todo lo que corre, se arrastra o vuela va a la cazuela, The New York Times, 13 May. Available at: https://www.nytimes.com/es/2017/05/13/espanol/a merica-latina/feria-gastronomica-mexico-mezquital.html (Accessed 11 May 2021)

SAGARPA, S. de A., Ganadería, Desarrollo Rural, Pesca y Alimentación. (2003) Resultados del Estudio del Diagnóstico Sectorial. Gobierno de Mexico. Available at: https://docplayer.es/ 10681820-Resultados-del-estudio-de-diagnostico-sectorial-en-elestado-de-hidalgo-2010.html (Accessed 31 May 2021)

Seth Denizen, K. (2021) Seth Denizen, 'Thinking Through Soil: Case Study from the Mezquital Valley', Harvard Graduate School of Design. Available at: https://www.gsd.harvard.edu/event/sethdenizen-thinking-through-soil-case-study-from-the-mezquital-va lley/ (Accessed 28 May 2021). 
SIAP (2018) Atlas Agroalimentario 2012 - 2018. SAGARPA. Available at: https://nube.siap.gob.mx/gobmx_publicaciones_sia p/pag/2018/Atlas-Agroalimentario-2018.

State of Hidalgo Government (2021) Available at: https://datamexico. org/es/profile/geo/hidalgo-hg

Tang B et al. (2020) An updated estimation of the risk of transmission of the novel coronavirus (2019-nCov). Infect Dis Model 5:248-255. https://doi.org/10.1016/j.idm.2020.02.001

Torkzaban, S. et al. (2006) Role of air-water interfaces on retention of viruses under unsaturated conditions, Water Resources Res, 42 (12). https://doi.org/10.1029/2006WR004904

Vallejo, J. A. et al. (2020) Predicting the number of people infected with SARS-COV-2 in a population using statistical models based on wastewater viral load, medRxiv, 2020.07.02.20144865. https:// doi.org/10.1101/2020.07.02.20144865

Wang S et al. (2020) High-throughput wastewater analysis for substance use assessment in central New York during the COVID-19 pandemic. Environ Sci: Process Impacts 22(11):2147-2161. https://doi.org/10.1039/D0EM00377H

Wang, W. et al. (2020) Detection of SARS-CoV-2 in Different Types of Clinical Specimens, JAMA. https://doi.org/10.1001/jama.2020.3786

$\mathrm{Wu}, \mathrm{F}$. et al. (2020) SARS-CoV-2 titers in wastewater foreshadow dynamics and clinical presentation of new COVID-19 cases, medRxiv, 2020.06.15.20117747. https://doi.org/10.1101/2020.06. 15.20117747

Wu F, Zhang J et al. (2020) SARS-CoV-2 titers in wastewater are higher than expected from clinically confirmed cases. mSystems 5(4):e00614-20. https://doi.org/10.1128/mSystems.00614-20

Zhang B et al. (2005) WebGestalt: an integrated system for exploring gene sets in various biological contexts. Nucleic Acids Res 33 (suppl_2):W741-W748. https://doi.org/10.1093/nar/gki475

Zhang X et al. (2020) Epidemiological, clinical characteristics of cases of SARS-CoV-2 infection with abnormal imaging findings. Int J Infect Dis 94:81-87. https://doi.org/10.1016/j.ijid.2020.03.040 